\title{
HEIGHT AND WIDTH PARAMETERS FOR ENSURING PASSAGE OF EXCESSIVE LOADS ON ROADS
}

\author{
Jan Petru*, Vladislav Krivda \\ VSB - Technical University of Ostrava, Faculty of Civil Engineering, Department of Transport Constructions, \\ Ludvika Podeste 1875, 70833 Ostrava-Poruba, the Czech Republic \\ * corresponding author: jan.petru@vsb.cz
}

\begin{abstract}
The article deals with the issues of a passage of excessive transport on the roads and with ensuring necessary height and width conditions for such transport in the Czech Republic. Currently, the regulations for designing roads for passage of excessive and oversize cargos are missing in the Czech Republic. Based on these aspects, the research in this area was done and the parameters for ensuring passage of excessive loads on the roads were determined. The article describes the issue of the transport within the Czech Republic, it also describes the created database of transport and its subsequent statistical analysis. Furthermore, it describes the process of determination of the resulting parameters, which should serve as a basis for the legislation and for creation of technical conditions.
\end{abstract}

KEYWORDS: excessive load; statistics; bridges; toll gates; vehicle distance; vertical clearance.

\section{INTRODUCTION}

The Czech Republic has a long tradition in engineering and industry. The industry sectors often produce products, which dimensions and weight can be considered as above-standard. A numerous problems occur with the transport of such products. Due to the clearance gauge and radius of arcs, it is difficult to use railway transport in the Czech Republic. Water transport is also not possible to be used to its full potential in our conditions. Therefore, it is necessary to carry out the transport on chosen routes of road infrastructure with the assistance of special vehicles.

Routes for excessive transport were previously protected by the Ministry of Transport in terms of dimensions and weight. However, the change occurred after 1992, when the routes for excessive transport were no longer protected by the Ministry of Transport. Recently, in the Czech Republic and abroad, new elements occur on roads, which result in calming the traffic and improved safety of the transport. These are the elements, which physically ensure the reduction of the speed of the vehicle. They are located on sections between junctions as well as on intersections and intersections both on level intersections and on overpass intersection in both urban and rural areas. Repeated deflections (chicanes), narrowing lanes by adding planted areas on sides, protective dividing islands for pedestrian crossings are used especially in urban areas. Dividing islands and routing islands are used at intersections on main and secondary roads. Currently, the number of roundabouts is also increasing. In particular, they can be found in cities, towns and on major roads. Roundabout helps to achieve traffic calming and have a significant impact on traffic safety. However, when suggesting the roundabouts in the routes of excessive transports, it is very important to pay attention to their design. Unfortunately, this type of transport and the above mentioned facts are very often not taken into consideration in the Czech Republic.

Companies, which specialize in escorting, transporting and realization of transport of excessive loads, spend more and more time and funds on ensuring technical adjustments of spatial arrangements of roads for the passage of individual oversized cargo.

The oversized transport does not include only products of engineering and industry. We must not forget various self-propelled and construction machinery, cranes that exceed the maximum standard limits by its weight or dimensions. The Ministry of Transport annually permits 15000 to 20000 oversized transports, of which approximately 5000 cargos, with respect to the size of the load, have extra spatial requirements for ensuring the passage.

At present, the conditions of the road network for passage of oversized cargo in the Czech Republic are unsatisfactory. Transporters and the escorts for oversized cargo face this fact regularly during the preparation of transport routes.

Similarly, bleak situation is in many other European countries. At the same time, there is the European Directive of best practices for the transport of oversized cargo by road from 17th May, 2006 [1], which recommends to the Member States to build a Europe-wide network of corridors for the transport of oversized cargo.

According to the Directive [1, Finland has, in most details, solved conditions for excessive transport. The Finnish network of roads for the transport of very large oversized cargo is predefined. It is a part of the road network, which is maintained in order to be operational for the transport of very large oversized cargo. It may not be expensive to consider the needs and requirement of the transport of oversized cargos in advance, while to subsequently do so, is often very ex- 

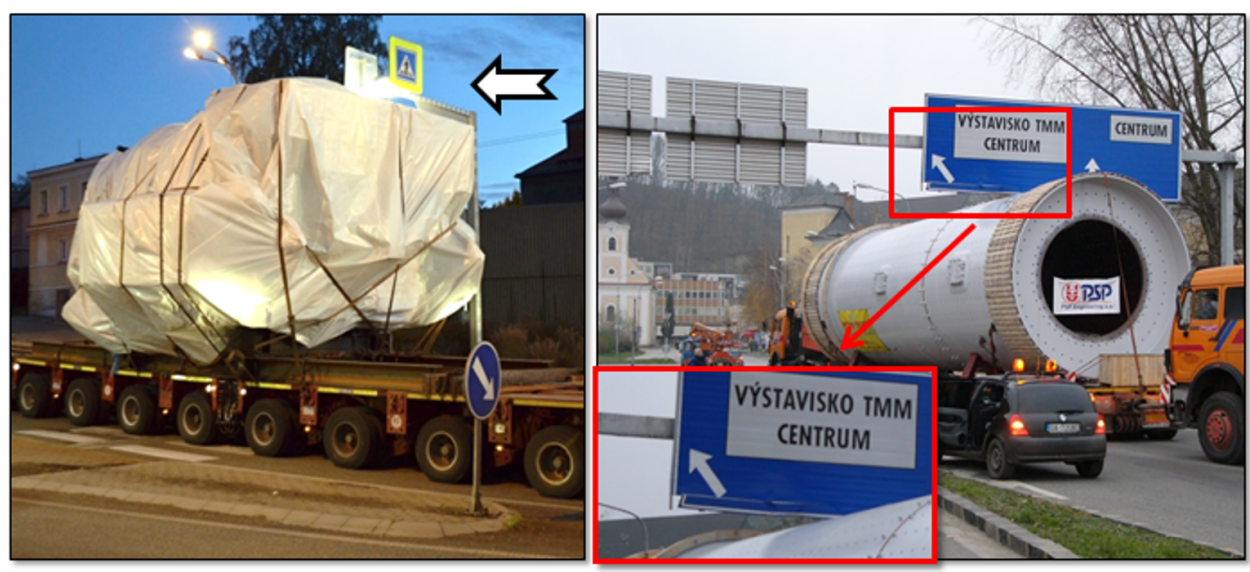

FiguRE 1. The problematic underpass under the traffic signs on the roads.
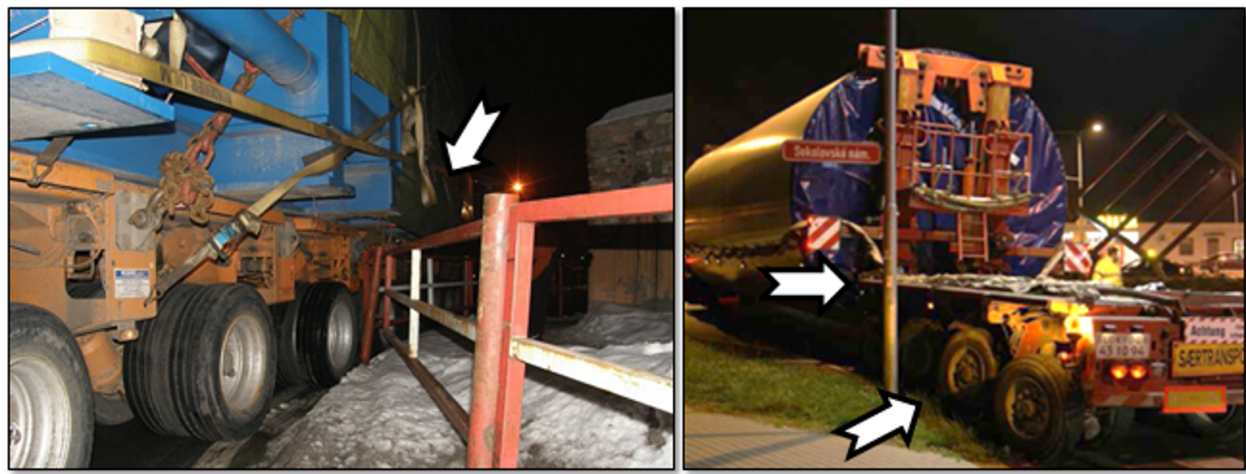

FiguRE 2. An example of a non-removable handrail and transit complications due to a proximity of public lighting.

pensive. Sometimes, it is even impossible to correct errors caused by planning or partial construction stages. In Finland, they consider it very important to keep in mind the requirements of transport of oversized cargos on roads and they take it into consideration when planning new roads and transport systems. In many cases, people who plan roads and transport systems do not have the sufficient information about the needs and requirements for the transport of oversized cargos on the road. Therefore, Finland has developed a set of standard values and instructions for dimensioning of road infrastructures [1, 2].

\section{ThE ISSUE OF TRANSIT ON FREQUENT ROUTES}

The passage of excessive and oversized cargo by road was discussed in detail with companies dealing with excessive shipping. The companies for escorting such cargos, such as CERESNAK, GARANTRANS Ltd., DOPROVODY Ltd., RP-DOPROVODY Ostrava were contacted. In addition, the transporters themselves were also contacted. The following companies were addressed: NOSRETI Inc., Petr Brezina APB Plzen Inc. and the company DAN-CZECH SPECIALTRANSPORT Ltd., who are the members of the Czech Association of Heavy and Oversize Transporters. Furthermore, measurements were carried out during the transports of excessive and oversized cargo [8].

\subsection{The Selection of Route}

The selection of route depends on the type of the cargo, its dimensions and weight. Route within the Czech Republic is chosen by the transporter, or the worker of the hired company (escort), and it is based on previous experience and the real conditions of the route. The final approval of the proposed route is granted by the competent administrative authority under an applicable law. The transporter is responsible for route selection and is obliged to check the route a day prior to the transport. The actual choice of route suggestion, due to the passage on the roads and ensuring static calculations of bridges or their support, may take even several months.

\subsection{TRAFFIC SIGNS AND IMMOBILE ELEMENTS ON ROADS}

The vertical traffic signs and their proximity to the road is a problematic element on roads. Furthermore, the signs, which are mounted on booms above the roads, are also a problem. They are mostly newly constructed or reconstructed pedestrian crossings. The boom is welded and it prevents any rotation during the passage of the cargo. If it is not possible to choose another alternative route, it is necessary to disassemble the boom. In such cases, there are very often time and financial losses.

It is not only about traffic signs, but there are also 

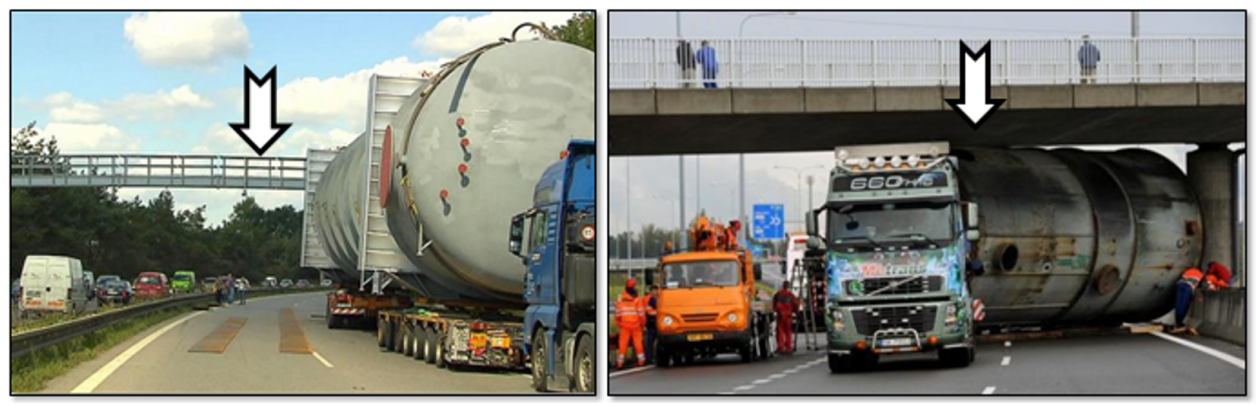

FiguRE 3. Preparing for the underpass of excessive cargo under the toll gate and the situation when the cargo got stuck under the bridge in Ostrava.

other problematic elements that, in our conditions, make it difficult or completely impossible to transport the cargo by road. These elements mainly include lighting, handrails, immobile elements, decorative elements and greenery. Lighting on roads brings similar problems as traffic signs. The poles are located close to the roads. Disassembly of lighting is very complex and the participation of relevant professional staff is necessary. In most cases, because of an unsuitable location of the lighting, the passage is not possible and it is necessary to choose another option of the route.

Non-removable handrail, which prevents the passage of the cargo, and other immobile elements on the route make the transport very difficult. And it is not only during the passage itself, but also during the planning of the route. In such cases, the section of the road or the junction becomes impassable for the cargo.

\subsection{VERTICAL CLEARANCE ON THE ROADS}

Transport routes are selected also with regard to the bridges. It is not just their load capacity, but also their vertical clearance. The vertical clearance is determined according to the CSN 736201 Design of Bridge Structures [7]. There is a given headroom at following types of roads:

- motorways, expressways and roads of the 1st and 2nd class - $4.80 \mathrm{~m}$;

- road of 3rd class and local and collecting roads $4.50 \mathrm{~m}$;

- local service roads and public utility roads $4.20 \mathrm{~m}$.

With the issue of a vertical clearance, the height clearance of tall gates and electric or other lines is connected. These height clearances often limit the passage of the cargo on individual roads and they very often require the assistance of others subjects.

Regarding the toll gates, they are normally designed to height clearance of $5.50 \mathrm{~m}$. The excessive loads using even the most modern types of trailers require a higher height. We can find portals adjusted to such transport on the road network within the Czech Republic. Their height ranges from $5.50 \mathrm{~m}$ to $5.90 \mathrm{~m}$ between the highest point of the road and the mounted technology without modifying the toll gate. After adjusting, the height reaches 7.85 meters, or up to completely free height space. Unfortunately, most of these toll gates are unsuitably fitted into the "backbone routes". When you need to modify one portal for the passage of an oversized cargo its informative price is CZK 63000 exclusive of VAT.

Networks of vertical power line, overhead lines or cables make transport very difficult in many places. In such cases, it is necessary to ensure the help of experts. The cables are lifted during the transport. Sometimes, there are cases when it is even necessary to shut down the electrical grid.

At intersections, such as rail crossings, or at the crossing of the road with tram line, there is a problem of passing under the overhead line. At intersections, the most frequent problem is the above-mentioned clearance under the bridges and the width for manoeuvring with the cargo, because it is very common to find many intersections, which have only one or two lanes on one side.

\section{AnAlysis of the DATA ABOUT TRANSPORT OF EXCESSIVE LOADS}

In order to determine the parameters for the passage of excessive loads in the Czech Republic, it is necessary to know the details about the transported cargos and vehicles that carry these loads.

It is an analysis of the data of used chassis types and their parameters - the collection of data (length, width, turning radius, using of pusher) from manufacturers of trailers and from transporters of the oversized cargos and the determination of the average and maximum values of observed parameters. Furthermore, it is an analysis of the data of the largest transported cargos - the collection of data (length, width, height, weight) from the transporters of oversized cargos, and also the determination of the average and maximum values of the observed parameters.

All the parameters needed to determine the width, height and length parameters sets were entered into a table that is for the period 2011-2013 (21.10.2013). This table has been compiled on the basis of ongoing research since 2011. The information was obtained from the visited transports, from transporters 


\begin{tabular}{|c|c|c|c|c|c|c|c|c|c|}
\hline $\begin{array}{l}\stackrel{0}{ \pm} \\
\stackrel{0}{0}\end{array}$ & 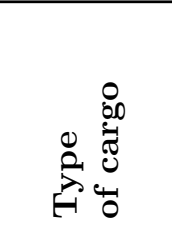 & 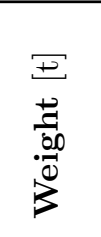 & 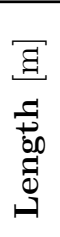 & 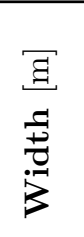 & 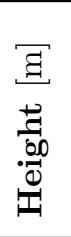 & 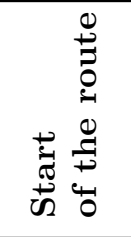 & 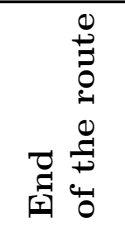 & $\begin{array}{c}\text { The course of route } \\
\text { (beginning, } \\
\text { intermediate place, } \\
\text { end) }\end{array}$ & $\begin{array}{l}\overbrace{0}^{n} \\
\frac{\sigma}{0} \\
\dot{0} \\
\dot{0} \\
\dot{0}\end{array}$ \\
\hline 10.-11. 1. 2011 & $\begin{array}{l}\text { Machine } \\
\text { equipment }\end{array}$ & 40 & 17 & 6 & 4.4 & Brno & Melnik & $\begin{array}{l}\text { Brno - Brno-Slatina D1 - } \\
\text { Pruhonice - Praha - } \\
\text { Melnik harbor }\end{array}$ & 2 \\
\hline 13. 1. 2011 & Generator & 232.4 & 36 & 4.95 & 5.5 & Plzen & Melnik & $\begin{array}{l}\text { Plzen - Krimice - } \\
\text { Mesto Touskov - Unesov - } \\
\text { Touzim - Bochov - Lubenec - } \\
\text { Bukov - Krusovice - } \\
\text { Revnicov - Msec - Turany - } \\
\text { Slany - Jesin - Nova Ves - } \\
\text { Spomysl - Melnik }\end{array}$ & 1 \\
\hline 14. 1. 2011 & $\begin{array}{l}\text { Machine } \\
\text { equipment }\end{array}$ & 60 & 33 & 4 & 4 & $\begin{array}{l}\text { Ceske } \\
\text { Budejo- } \\
\text { vice }\end{array}$ & Pisek & $\begin{array}{l}\text { C. Budejovice - Tabor - } \\
\text { Milevsko - Milin - } \\
\text { Velka Chuchle I/19 - Pisek }\end{array}$ & 1 \\
\hline
\end{tabular}

TABLE 1. Statistics of the Czech Republic in the years 2011-2013.

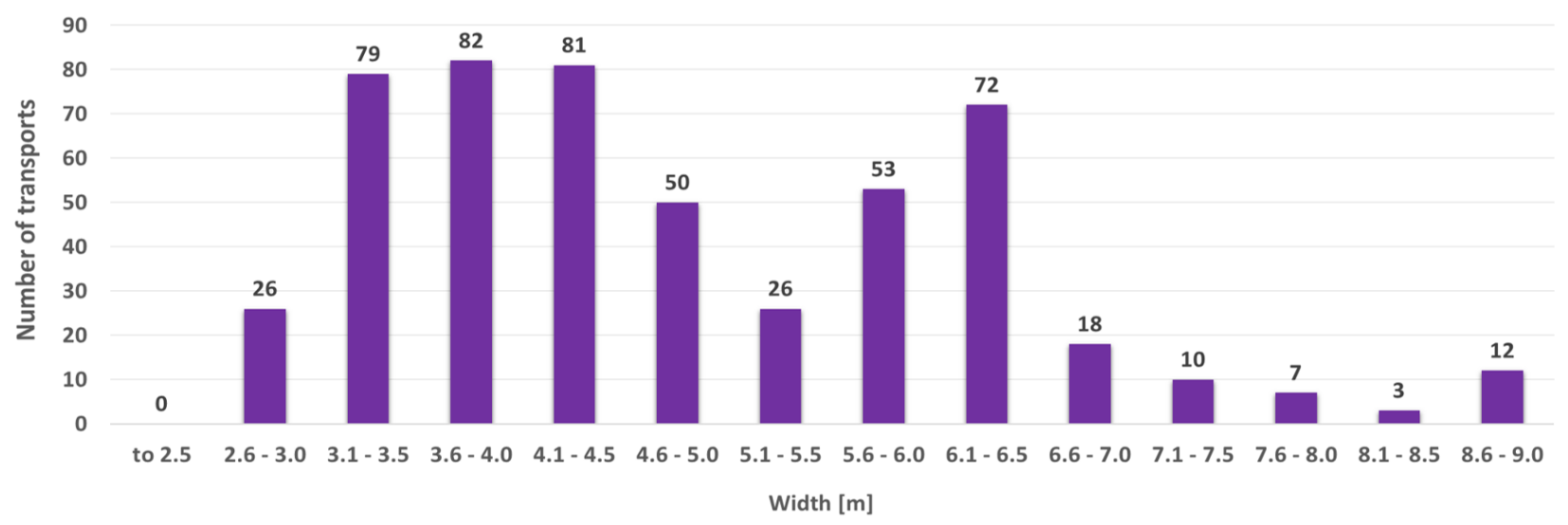

Figure 4. The number of transports in the range of widths of sets of excessive loads in the Czech Republic for the years 2011-2013.

of excessive and oversized cargo, escorts, the police of the Czech Republic and information from the Internet. In the table, there not all transports that were realized in that period are entered. However, the entered transports serve as a sufficient sample for determining the parameters. There is 519 processed transports in the table. These are transport of generators, transformers, structures, trusses, bridge parts, heavy presses, construction machinery, cranes, machines and their parts and other types of transport, which, by its size or weight, can be considered non-standard transports, and which must obtain a permit.

Transports were divided according to the year of transport, type of the transported cargo, weight, length, width, height. To determine the most frequent transport routes, other criteria were also observed, such as the start and the end of the transport route and its entire course. The information was further complemented by the number of the days of the transport. The preview of the data processed in the table is shown in Table 1 .

Acquired data were processed and charts and graphs were created, which served for subsequent determination of the final parameters. For example, the data in Figure 4 show the number of transports within the scope of the width of excessive cargo in the Czech Republic in 2011-2013. The highest number of transports was reached within the scope between 3.1 to 4.5 meters - a total of 242 transports. Significant number of transports ranges within the scope of 6.1 to 6.5 - a total of 72 transports.

For illustration, the data about the height of transport are also provided. The height of transport ranged from $3.00 \mathrm{~m}$ to $7.40 \mathrm{~m}$. The average height of all transported loads was $4.50 \mathrm{~m}$. The graphic representation of the height of the transported loads is shown in Figure 5. The highest numbers of transports are in 


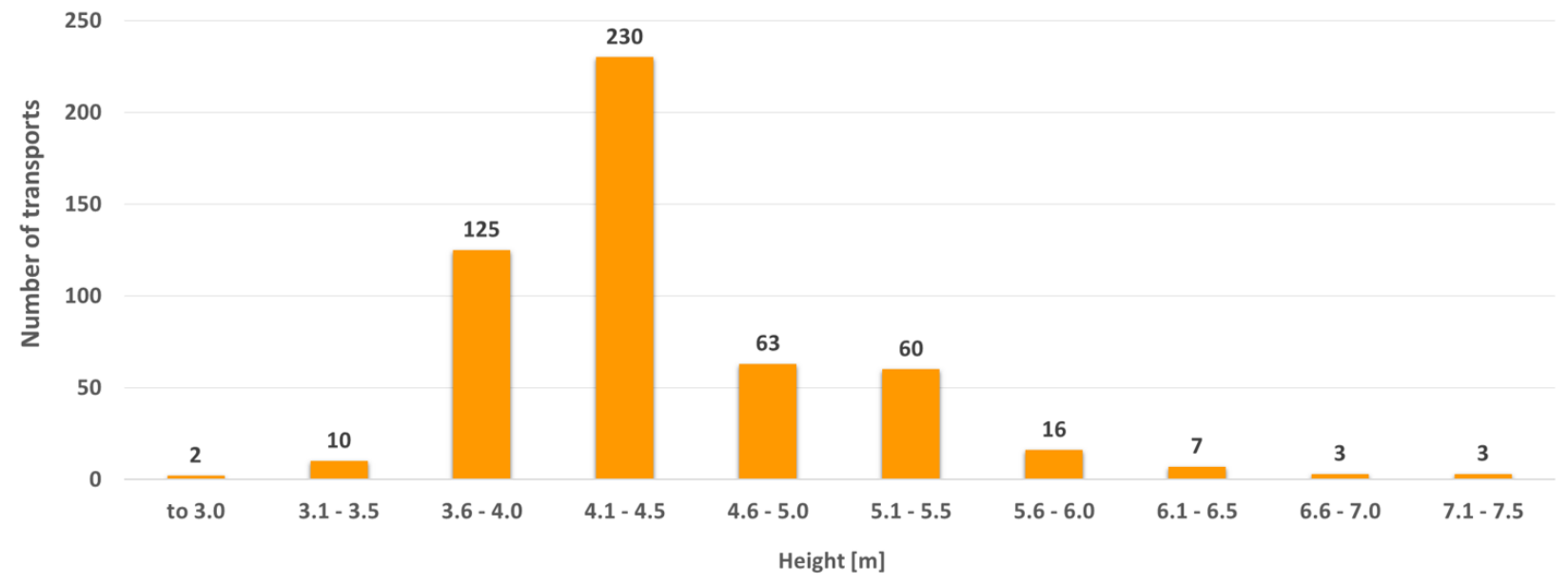

FiguRE 5. The number of transports in the range of heights of sets of excessive load in the Czech Republic for years 2011-2013.

\begin{tabular}{lcccc}
\hline \multicolumn{1}{c}{ Indicator } & Weight $[\mathrm{t}]$ & Length $[\mathrm{m}]$ & Width $[\mathrm{m}]$ & Height $[\mathrm{m}]$ \\
\hline Minimum & 5.5 & 7 & 2.75 & 3 \\
Maximum & 466 & 72 & 8.8 & 7.4 \\
Average & 108.07 & 25.96 & 4.89 & 4.5 \\
\hline The average deviation & 80.2 & 8.64 & 1.16 & 0.43 \\
The standard deviation of & 96.103 & 11.0112 & 1.3771 & 0.6098 \\
\hline Modus & 10 & 23 & 4 & 4 \\
Median & 65.4 & 23 & 4.5 & 4.4 \\
\hline Skewness & 1.1909 & 0.9883 & 0.7161 & 1.4323 \\
Spikiness & 1.1118 & 1.4262 & -0.0112 & 3.6561 \\
\hline
\end{tabular}

TABLE 2. The list of all types of processed statistical indicators of transports in the Czech Republic for years 2011-2013.

the range from 4.1 to $4.5 \mathrm{~m}$ (a total of 230 transports) and from $3.6 \mathrm{~m}$ to $4.0 \mathrm{~m}$ (a total of 125 transports), and there was also a large number of transports with a height bigger than the height clearance, which is required by the regulation for bridges.

Further, the statistical indicators, which help to more precisely determine the parameters of the transported cargos, were evaluated. The list of statistical indicators was subsequently used as a basis for determining the parameters that should be ensured during transport on frequent routes of these transports. The statistically processed data are shown in Table 2.

\subsection{STATISTICAL DATA FOR INDIVIDUAL LOADS}

To be able to specify, in detail, the distance of placement of traffic signs on roads, the height clearance and parameters of intersections, it was necessary to create models of vehicles according to the most common types of transport. This is about dimensions (height and width) according to the type of cargo. Different types of loads use different types of trailers on which the cargo is transported. It's not always true that longer trailers have worse manoeuvrability than shorter ones. Similar parameters also apply to the width and height parameters.

For these reasons, the transports of excessive and oversized cargo are divided into six categories - see Table 3 For each category, it was necessary to identify all dimensions, which were then used for modelling the vehicle in program AutoTURN or EasyTrack, but they were also used to determine parameters of intersections for certain types of cargo. It was done because the parameters of intersections were also determined in the scope of this project.

Cargo itself can be transported on multiple types of trailers. The crucial elements for choosing the right one are the size of the load, its shape and weight. These aspects were subsequently separated during modelling of the vehicles themselves. Parameters for the routes can be determined generally on all routes, or just for the most common types of cargos that are transported on these routes. On some routes, there are, for example, transported only generators, transformers, and on other routes only components of structures or machinery. It is true that the different types of transport require different parameters of intersections. It is not always necessary to have routes and their parameters created for all types of transportations. 


\begin{tabular}{|c|c|c|c|c|c|}
\hline $\begin{array}{l}\text { Long and heavy } \\
\text { transport }\end{array}$ & Construction & Components & Machinery & $\begin{array}{l}\text { Machinery } \\
\text { equipment }\end{array}$ & $\begin{array}{l}\text { Mixed } \\
\text { category }\end{array}$ \\
\hline $\begin{array}{l}\text { Generators } \\
\text { Transformers } \\
\text { etc. }\end{array}$ & $\begin{array}{l}\text { Trusses } \\
\text { Frame } \\
\quad \text { construction } \\
\text { Bridge } \\
\quad \text { construction } \\
\text { Steel } \\
\quad \text { construction } \\
\text { Wood } \\
\text { construction } \\
\text { Concrete } \\
\text { construction } \\
\text { Beam } \\
\text { etc. }\end{array}$ & $\begin{array}{l}\text { Part of the } \\
\text { press } \\
\text { Hatches } \\
\text { Cylinder } \\
\text { Ring } \\
\text { Section the } \\
\text { mill } \\
\text { Steel } \\
\text { containers } \\
\text { Steel bottom } \\
\text { etc. }\end{array}$ & $\begin{array}{l}\text { Construction } \\
\text { machinery } \\
\text { Other types of } \\
\text { machines } \\
\text { Parts of the } \\
\text { crane } \\
\text { etc. }\end{array}$ & $\begin{array}{l}\text { Machinery } \\
\text { equipment } \\
\text { Parts of } \\
\text { machinery } \\
\text { etc. }\end{array}$ & $\begin{array}{l}\text { Technological } \\
\quad \text { equipment } \\
\text { Boat } \\
\text { Building cells } \\
\text { Heat covers } \\
\quad \text { shields } \\
\text { Pools } \\
\text { Silo } \\
\text { Aircraft } \\
\quad \text { fuselage } \\
\text { etc. }\end{array}$ \\
\hline
\end{tabular}

TABLE 3. Categories for allocation of cargo.

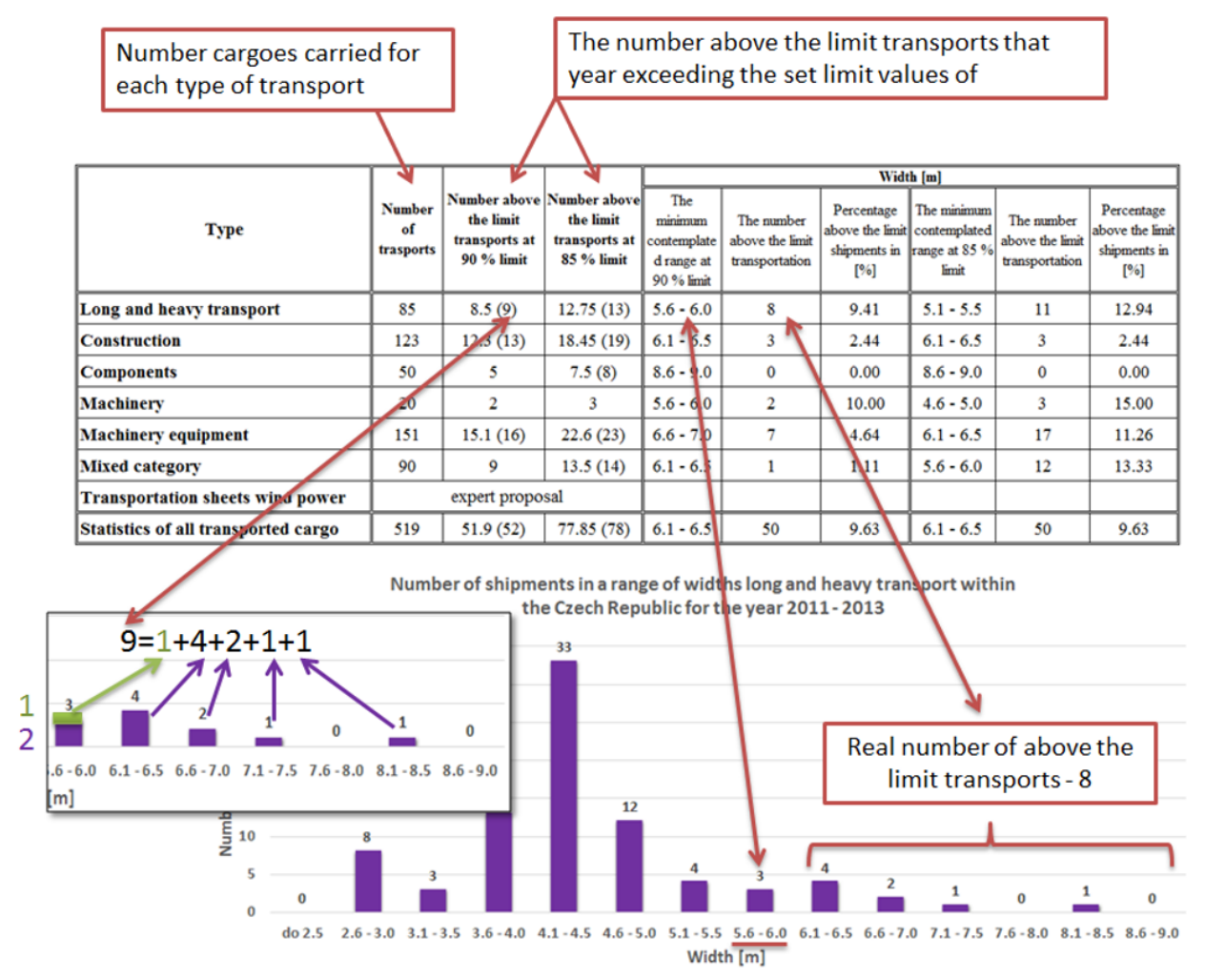

FiguRE 6. Graphical representation of a process to determine the number of excess loads for $90 \%$ of the number of transports.

\subsection{Overall evaluation}

\section{OF STATISTICAL DATA OF TRANSPORTS IN THE CZECH REPUBLIC}

On the basis of statistics results, the process was suggested for determination of resulting values. This process is processed in several tables. First, it was necessary to determine the number of excess transports according to the type of cargo. All tables show the type of cargo and its number. Based on the list of processed statistical indicators and economic perspective, it is not financially profitable to establish a route for $100 \%$ of transported cargos (if the excess transport is realized, for example, once in 3 years), the percentage number of transports was determined. This is the number of transports for which the route should be designed (90\% and $85 \%$ ). For individual types of cargo and monitored values (weight, length, width and height of the cargo), the actual number of excess transports, which exceed $90 \%$ and $85 \%$, was identified.

Graphical representation of how to determine the number of excessive transports depending on the type of cargo is shown in Figure 6 . 


\begin{tabular}{|c|c|c|c|c|c|c|c|c|c|}
\hline \multirow[b]{2}{*}{ Type } & \multirow[b]{2}{*}{$\begin{array}{c}\text { Number } \\
\text { of } \\
\text { trasports }\end{array}$} & \multirow{2}{*}{$\begin{array}{c}\begin{array}{c}\text { Number } \\
\text { above the } \\
\text { limit } \\
\text { transports at } \\
90 \% \text { limit }\end{array} \\
\end{array}$} & \multirow{2}{*}{$\begin{array}{c}\text { Number above } \\
\text { the limit } \\
\text { transports at } \\
85 \% \text { limit }\end{array}$} & \multicolumn{3}{|c|}{ Width [m] } & \multicolumn{3}{|c|}{ Height [m] } \\
\hline & & & & $\begin{array}{c}90 \% \\
\text { transports + } \\
5 \% \text { to width }\end{array}$ & $\begin{array}{c}85 \% \\
\text { transports + } \\
5 \% \text { to width }\end{array}$ & $\begin{array}{c}\text { Recommended } \\
\text { proposal }\end{array}$ & $\begin{array}{c}90 \% \\
\text { transports + } \\
5 \% \text { to height }\end{array}$ & $\begin{array}{c}85 \% \\
\text { transports + } \\
5 \% \text { to height }\end{array}$ & $\begin{array}{c}\text { Recommended } \\
\text { proposal }\end{array}$ \\
\hline Long and heavy transport & 85 & $8,5(9)$ & $12,75(13)$ & 6.3 & 5.775 & 6.30 & 5.775 & 5.775 & 5.80 \\
\hline Construction & 123 & $12,3(13)$ & $18,45(19)$ & 6.825 & 6.825 & 6.90 & 4.725 & 4.725 & 4.80 \\
\hline Components & 50 & 5 & $7,5(8)$ & 9.45 & 9.45 & 9.50 & 6.3 & 5.775 & 6.30 \\
\hline Machinery & 20 & 2 & 3 & 6.3 & 5.25 & 6.30 & 4.725 & 4.725 & 4.80 \\
\hline Machinery equipment & 151 & $15,1(16)$ & $22,6(23)$ & 7.35 & 6.825 & 7.40 & 6.3 & 5.775 & 6.30 \\
\hline Mixed category & 90 & 9 & $13,5(14)$ & 6.825 & 6.3 & 6.90 & 4.725 & 4.725 & 4.80 \\
\hline Transportation sheets wind power & \multicolumn{3}{|c|}{ expert proposal } & 3.5 & 3.5 & 3.50 & 4.8 & 4.8 & 4.80 \\
\hline Statistics of all transported cargo & 519 & $51,9(52)$ & $77,85(78)$ & 6.825 & 6.825 & 6.90 & 5.775 & 5.775 & 5.80 \\
\hline BACKBONE ROUTE - DRAFT & & & & \multicolumn{3}{|c|}{9.50} & \multicolumn{3}{|c|}{6.30} \\
\hline
\end{tabular}

TABLE 4. The resulting values of widths and heights for transporting oversized cargo.

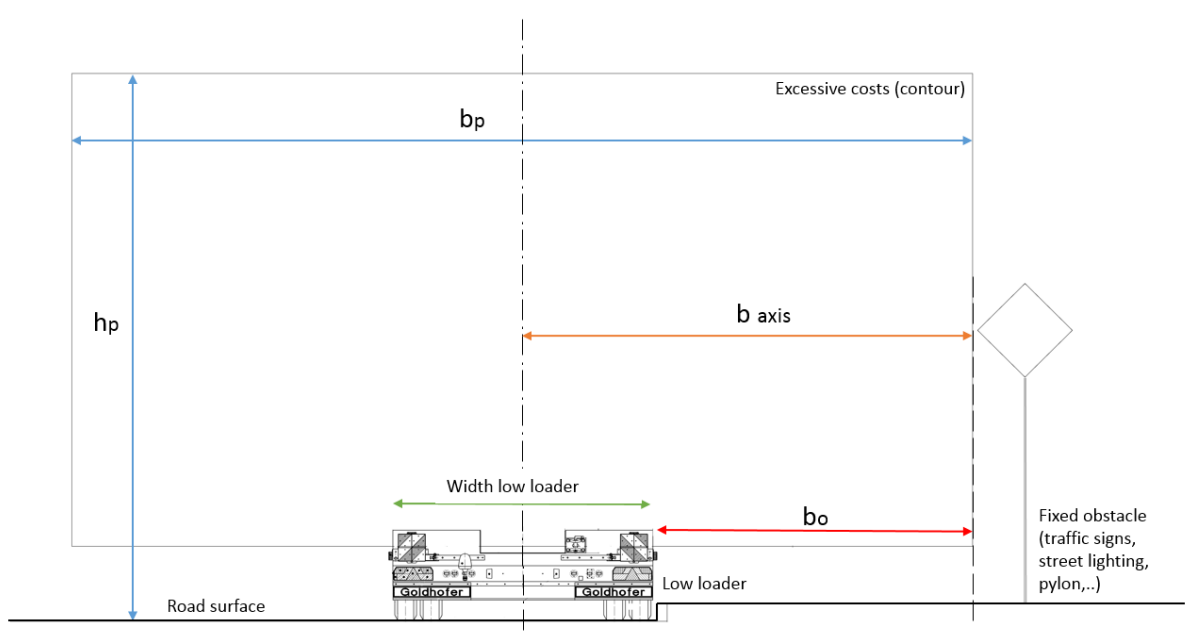

FIGURE 7. Diagram of clearance gauge including the distance from solid obstacles.

The lines in the tables with the statistics of all transported loads are not the average values from the types of transports, but the resulting values are evaluated separately from the overall statistics of 519 transports. Statistical sample did not include transports of wind turbines, the resulting values were determined by expert suggestion after consulting with the companies involved in the transport of excessive and oversized cargo.

From such determined number of excessive transports and the calculated range in which transports move, the resulting values were processed. To remove potential errors in the statistical sample, the safety addition of $5 \%$ was calculated to the highest range into which 90 and $85 \%$ of the number of transports belong to. This addition also eliminates errors during the measurement of cargo (sets of excessive or oversized cargos) and it also includes a safety margin for determining the clearance space (width, height), tolerance in modelling of swept path (width, height, length) and the bearing capacity for bridges (weight). This $5 \%$ addition meets all the above mentioned criteria.

The resulting tables contain the resulting data for $90 \%$ and $85 \%$ of transports, including the addition of $5 \%$, on which the parameters of routes for the transport of individual types of loads and parameters for determining the backbone routes should be defined. The values for $85 \%$ of transports, including the addition of $5 \%$ - these values were determined as the minimum values (85\% of transports - minimum requirements for passage). Values for $90 \%$ of transports, including the addition of $5 \%$ - these values include the routes where local conditions like width, height and weight, or other aspects do not restrict their suggestion. The table also contains a recommended suggestion - which the route should meet for transporting mentioned types of cargo. For suggesting the backbone routes, the stated values must be kept.

Resulting values (Table 4), which are shown in the tables, were used to determine the clearance space. The parameters of resulting values were further used for modelling of excessive and oversized sets and for verification of swept path in the area of intersections.

\section{Clearance gauge and the DISTANCE FROM SOLID OBSTACLES}

Clearance gauge and the distance from solid obstacles were determined on the basis of the processed statistics in the Czech Republic. The diagram of clearance gauge is shown in Figure 7 . For the calculated clear- 


\begin{tabular}{||l||c||c|c|c||c|c|c||}
\hline \multicolumn{1}{|c|}{ Type } & $\begin{array}{c}\text { The minimum } \\
\text { width used } \\
\text { low loader } \\
\text { [m] }\end{array}$ & $\begin{array}{c}\text { Optimal - for } \\
\mathbf{9 0 \%} \text { of } \\
\text { transports }\end{array}$ & $\begin{array}{c}\text { min. - 85\% } \\
\text { of of } \\
\text { transports }\end{array}$ & $\begin{array}{c}\text { Recommended } \\
\text { proposal }\end{array}$ & $\begin{array}{c}\text { optimal } \\
\text { rounded } \\
\text { to }\end{array}$ & $\begin{array}{c}\text { min. } \\
\text { rounded } \\
\text { to }\end{array}$ & Recommended \\
\hline \hline Long and heavy transport & $\mathbf{3 . 0 0}$ & 6.3 & 5.775 & $\mathbf{6 . 3 0}$ & 3.15 & 2.90 & $\mathbf{3 . 1 5}$ \\
\hline Construction & $\mathbf{2 . 5 5}$ & 6.825 & 6.825 & $\mathbf{6 . 9 0}$ & 3.45 & 3.45 & $\mathbf{3 . 4 5}$ \\
\hline Components & $\mathbf{2 . 5 5}$ & 9.45 & 9.45 & $\mathbf{9 . 5 0}$ & 4.75 & 4.75 & $\mathbf{4 . 7 5}$ \\
\hline Machinery & $\mathbf{2 . 5 5}$ & 6.3 & 5.25 & $\mathbf{6 . 3 0}$ & 3.15 & 2.65 & $\mathbf{3 . 1 5}$ \\
\hline Machinery equipment & $\mathbf{2 . 7 5}$ & 7.35 & 6.825 & $\mathbf{7 . 4 0}$ & 3.70 & 3.45 & $\mathbf{3 . 7 0}$ \\
\hline Mixed category & $\mathbf{2 . 5 5}$ & 6.825 & 6.3 & $\mathbf{6 . 9 0}$ & 3.45 & 3.15 & $\mathbf{3 . 4 5}$ \\
\hline Transportation sheets wind power & $\mathbf{2 . 5 2}$ & 3.5 & 3.5 & $\mathbf{3 . 5 0}$ & 1.75 & 1.75 & $\mathbf{1 . 7 5}$ \\
\hline Statistics of all transported cargo & $\mathbf{2 . 5 2}$ & 6.825 & 6.825 & $\mathbf{6 . 9 0}$ & 3.45 & 3.45 & $\mathbf{3 . 4 5}$ \\
\hline BACKBONE ROUTE - DRAFT & $\mathbf{2 . 5 2}$ & & $\mathbf{9 . 5 0}$ & & & $\mathbf{4 . 7 5}$ \\
\hline
\end{tabular}

TABLE 5. The width of clearance space including the distance from the axis to the edge of the contour of the cargo. Note that the statistics of all transported cargo is not an average of the type of transport but the results are evaluated separately from the overall statistics of 519 transports.

\begin{tabular}{|c|c|c|c|c|c|c|c|}
\hline \multirow[b]{2}{*}{ Type } & \multirow{2}{*}{$\begin{array}{c}\text { The minimum } \\
\text { width used } \\
\text { low loader } \\
{[\mathrm{m}]}\end{array}$} & \multicolumn{3}{|c|}{ bo [m] } & \multicolumn{3}{|c|}{ Height hp [m] } \\
\hline & & $\begin{array}{l}\text { optimal } \\
\text { rounded } \\
\text { to }\end{array}$ & $\begin{array}{c}\text { min. } \\
\text { rounded to }\end{array}$ & Recommended & $\begin{array}{c}\text { optimal - for } \\
90 \% \text { of } \\
\text { transports }\end{array}$ & $\begin{array}{c}\text { min. - } 85 \% \\
\text { of of } \\
\text { transports }\end{array}$ & $\begin{array}{c}\text { Recommended } \\
\text { proposal }\end{array}$ \\
\hline Long and heavy transport & 3.00 & 1.65 & 1.40 & 1.65 & 5.775 & 5.775 & 5.80 \\
\hline Construction & 2.55 & 2.20 & 2.20 & 2.20 & 4.725 & 4.725 & 4.80 \\
\hline Components & 2.55 & 3.50 & 3.50 & 3.50 & 6.3 & 5.775 & 6.30 \\
\hline Machinery & 2.55 & 1.90 & 1.40 & 1.90 & 4.725 & 4.725 & 4.80 \\
\hline Machinery equipment & 2.75 & 2.35 & 2.10 & 2.35 & 6.3 & 5.775 & 6.30 \\
\hline Mixed category & 2.55 & 2.20 & 1.90 & 2.20 & 4.725 & 4.725 & 4.80 \\
\hline Transportation sheets wind power & 2.52 & 0.50 & 0.50 & 0.50 & 4.8 & 4.8 & 4.80 \\
\hline Statistics of all transported cargo & 2.52 & 2.20 & 2.20 & 2.20 & 5.775 & 5.775 & 5.80 \\
\hline BACKBONE ROUTE - DRAFT & 2.52 & \multicolumn{3}{|c|}{3.50} & \multicolumn{3}{|c|}{6.30} \\
\hline
\end{tabular}

TABLE 6. The distance from solid obstacles and height of clearance space. Note that the statistics of all transported cargo is not an average of the type of transport but the results are evaluated separately from the overall statistics of 519 transports.

ance gauge, similar requirements as for the clearance gauge in chapter 6.1.2. of the CSN 736201 Design of Bridges [?] are valid.

The width of clearance space bp for passage of oversized cargo is listed in Table 5 . This table also contains the distance from the axis of the trailer to the edge of the contour of the oversized cargo b axis (bp/2 - rounded). For individual types of cargo, fixed distances are determined depending on the passage of $90 \%$ of transports (optimal value), passage of $85 \%$ of transports (minimum value) and the recommended distances.

The distance from solid obstacles bo (traffic signs, street lighting poles, railings, grown greenery, safety barriers, etc.) is presented in Table 6. This distance depends on the type of transport and the minimum width of the transport trailer on which the oversized cargo is transported. For individual types of transports distances, depending on the passage of $90 \%$ transports (optimal value), a passage of $85 \%$ of trans- port (minimum value) and the recommended distances are set. On the backbone routes, the values specified in the table should be followed. The minimum width of used trailer was determined according to the type of cargo and the distribution of these vehicles into categories.

The value of bo was calculated as

$$
b_{\mathrm{o}}=b_{\mathrm{osa}}-\frac{x}{2},
$$

where $x$ is the minimum width of used trailer.

The height of the clearance space $h p$ is given in Table 6. This height was determined on the basis of processed statistics of transport in the Czech Republic. Heights depending on the passage of $90 \%$ of transports (optimal value), $85 \%$ of transports (minimum value) and the recommended heights are set for individual types of cargo. On the backbone routes, the values specified in the table should be followed. The height of the clearance space is the basis for the free height 
of the underpass, which is stated in section 6.3.2. of the CSN 736201 Design of Bridges.

\section{Conclusion}

On the basis of the research, which was aimed at the issue of transport of excessive loads on the roads and ensuring the necessary height and width conditions for such transport in the Czech Republic, the height and width parameters for the transport were determined. Currently, from the Czech Association of Heavy and Oversize Transporters and manufacturing companies in the Czech Republic, there is an initiative to create a regulation that would set the parameters for passage of excessive and oversized cargo on the roads. This research should serve as one of the bases for solving this problem (i.e. a basis for processing the technical conditions). These parameters can be used in urban and rural areas, on intersections, on roundabouts and during the design and reconstruction of intersections. There is also an effort to use these determined parameters as the basis for changes to legislation in the Czech Republic.

The article mentions only examples of the overall processed statistics. Determination of heights and widths of transports is only one part of the total performed research that builds on the research activities of the authors in the research group of Civil Engineering, within the scope of the project Creation and Internationalization of Top Scientific Teams and Increasing their Excellence at the Faculty of Civil Engineering, VSB-TUO (CZ.1.07/2.3.00/20.0013), and then to the Student Grant Competition for 2012 called Swept Path of Oversize Vehicles and Student Grant Competition for 2013 called Mobile Camera for Transport and Construction Research.

\section{ACKNOWLEDGEMENTS}

The work was supported from the sources for conceptual development of research, development and innovations for 2016 at the VSB-Technical University of Ostrava which were granted by the Ministry of Education, Youths and Sports of the Czech Republic.

\section{REFERENCES}

[1] European Best Practice Guidelines for Abnormal Road Transports. European Commission Directorate General for Energy and Transport, 2006. http:

//ec.europa.eu/transport/road_safety/vehicles/ doc/abnormal_transport_guidelines_en.pdf [2013-01-30].

[2] Hanna, S., Erikoiskuljetustoiminta tienpitäjän näkökulmasta. Tiehallinnon selvityksiä, 2003.

http://www.ely-keskus.fi/fi/Liikenne/Lupaasiat/ Erikoiskuljetukset/Tilastot/Documents/ Erikoiskuljetukset_tienpitajan_nakokulmasta.pdf [2013-01-30].

[3] GIUFFRÈ, Orazio, Anna GRANA, Sergio MARINO a Fabio GALATIOTO. Passenger Car Equivalent for Heavy Vehicles Crossing Turbo-roundabouts. Transportation Research Procedia, 14, 4190-4199, 2016. DOI:10.1016/j.trpro.2016.05.390

[4] MOKHTAR, M. O. A., I. M. IBRAHIM a A. M. EL-BUTCH. New Suspension Design for Heavy Duty Trucks: Dynamic Considerations. http://papers.sae.org/2000-01-3447/ [2016-12-02]. DOI:10.4271/2000-01-3447

[5] MAURO, Raffaele, Marco CATTANI a Marco GUERRIERI. Evaluation of the safety performance of turbo roundabouts by means of a potential accident rate model. THE BALTIC JOURNAL OF ROAD AND BRIDGE ENGINEERING, 10(1), 28-38, 2015. DOI:10.3846/bjrbe.2015.04

[6] CSN 73 6201. Design of Bridges. Praha: Czech Standards Institute, 2008.

[7] Decree no. 341/2002 Coll., On approval of technical qualification and technical conditions for operating vehicles on roads, Prague: Ministry of Transport and Communications, 2002.

[8] KRIVDA, Vladislav, Ivana MAHDALOVA a Jan PETRU. Use of Video Analysis of Conflict Situations for Monitoring of Traffic on Urban Road Influenced by Parallel Parking. Communications. Zilina: University of Zilina, 15(3), 118-125, 2013. 